International Journal of Agriculture, Environment and Bioresearch

Vol. 5, No. 01; 2020

ISSN: $2456-8643$

\title{
IN VITRO PROPAGATION PROTOCOL OF JASMINUM POLYANTHUM USING INDIRECT ORGANOGENESIS
}

\author{
El-Sadat, N.H.A. ${ }^{1}$ and Hewidy, M. ${ }^{2 *}$ \\ 1Applied Research Center of Medicinal Plants and Natural Products, National Organization for Drug Control and \\ Researches, Cairo, Egypt \\ ${ }^{2}$ Hortic. Dept., Fac. of Agric., Ain Shams Univ., P.O. Box 68, Hadayek Shobra 11241, Cairo, Egypt \\ https://doi.org/10.35410/IJAEB.2020.5456
}

\begin{abstract}
Jasminum polyanthum is an important ornamental plant belonging to the Oleaceae family. Both shoot tip and leaves were used as explant for the induction of shoots via indirect organogenesis. For callus induction, explants were excised from field grown mature plants and thereafter incubated on MS basal medium supplied by $1.0 \mathrm{mg} / \mathrm{l}$ BA supplemented with various concentrations of 2,4-dichlorophenoxyacetic acid (2,4-D) at 0.0, 1.0, 2.0, 4.0 and $6.0 \mathrm{mg} / \mathrm{l}$. Maximum percentage of callus induction from both explants was procured by the application of 2,4-D at $2.0 \mathrm{mg} / \mathrm{l}$. Significant release of callus induction was swelled from leaf explants when compared to shoot tips at different 2,4-D levels. For the proliferation stage, induced callus was transferred into MS supplemented with BA at 0.0, 1.0, 2.0 and $3.0 \mathrm{mg} / \mathrm{l}$ along with NAA at 0.0 , 0.5 and $1.0 \mathrm{mg} / \mathrm{l}$. The maximum percentage of shoot proliferation per culture was achieved from callus cultured in $1.0 \mathrm{mg} / \mathrm{L} \mathrm{BA}$ along with $0.5 \mathrm{mg} / 1 \mathrm{NAA}$. For rooting, microshoots were treated with either IBA or IAA at $0.0,0.5,1.0$ and $2.0 \mathrm{mg} / \mathrm{l}$. Maximum rooting formation (Number and length) was recorded by the application of IBA at $2.0 \mathrm{mg} / \mathrm{l}$. For acclimatization, the complete plantlets grown in pots filled with peat moss + vermiculite was suitable for $91 \%$ plantlets to survive.
\end{abstract}

Keywords: Jasminum polyanthum, Indirect organogenesis, Callus, BA, 2,4-D, IBA, IAA.

\section{INTRODUCTION}

Jasminum is a wide spread genus which includes Jasminum polyanthum, that is known also as pink jasmine and many-flowered jasmine. It is a perennial creeper native to south-west of Chinese territory. Jain $\boldsymbol{e t}$ al. (2011) attested that $J$. polyanthum has many medicinal effects, i.e. pain-relieving, anti-stress, antibacterial, expectorant, aphrodisiac, calming, stomach tone, diuretic, depurative, skin lotion, immune-booster, anti-oxidant, anthelmintic and antiinflammatory, in normal. Its aesthetic derives from it as strong growth and can raise up to 6 meters in length when sustained. It produces a great quantity of white flower cluster with some reddish in end of winter to beginning of spring. Petals are five-petal headed in star-like $2 \mathrm{~cm}$ in diameter, holding aromatic scent. Plant leaves are compound, formed of five to nine leaflets which are dark/lighter green on the upper/lower surfaces (Harrison, 2012). Its growth is suitable 
Vol. 5, No. 01; 2020

ISSN: 2456-8643

for cool outdoor conditions in home-garden or in designed landscape. Rahman et al. (2018) explored the possibility of propagation for Jasminum species by seed or by suckers. They showed the possibility of propagation of Jasminum grandiflorum via in vitro propagation. The supplies of various ornamental and cut flower plants is accepted though tissue culture at commercial level (Dadlani, 1998). The clonal population reliability may be missing in population propagated by normal seed development method due to genetic variability manifestation of seeds.

Bhattacharya and Bhattacharyya (2010) set a procedure for in vitro proliferation of $J$. officinale by newly developed adventitious axillary buds via proper phytohormonal stimulation. In earlier in vitro culture studies made by Jonard (1989) and Bhattacharya and Bhattacharyya (1997) showed use of nodal explants.

Cytokinin mainly helps in the multiplication stage on increase proliferation rate and quality (Hassan et al., 2019). Ojha et al., (2012) mentioned that the combination between auxin 2,4-D and cytokinins improved of callus induction and maintenance of Stevia rebaudiana plants. There is a large interest for beautiful and fragrant plants cultivated under Egyptian condition like Jasminum polyanthum. Thus, the aim of this study was to increase the availability via providing mass production protocol for Jasminum polyanthum through tissue culture technique that offers great potential for the establishment of plantlets from induced indirect shoot regeneration method using shoot tips or leaves callus as explants.

\section{MATERIAL AND METHODS}

This research was performed in the laboratory of in vitro culture at Applied Research Center of Medicinal Plants and Natural Products in National Organization for Drug Control and Researches, Cairo, Egypt during the period from 2016-2018.

\section{Source of explant and basal medium:}

Two different explants (shoot tip and leaf) of Jasminum polyanthum were collected from young shoots (one month old) from a two years old plant, grown in the Applied Research Center of Medicinal Plants and Natural Products, growing beside the green house of the laboratory of tissue culture. The explants were defoliated and washed carefully in fluid tap water to eliminate all the stacked dust/soil practices. Tailed with surface sterilization of the explants were using $70 \%$ ethanol for a minute, and lastly by $0.1 \% \mathrm{HgCl}_{2}$ for 1 to 2 min and washed 4 to 5 times with double distilled sterile water. Excising and procedure of culture for explants (shoot tips and meristemic leaves) were performed under the laminar air flow hood. The shoot tip explants were cut under microscope to about $0.2-0.5 \mathrm{~mm}$ in length while, leaves explants were excised into 10 discs at $5 \mathrm{~mm}$ per each.

MS basal medium contains required nutrients of macro- and micro-elements for the in vitro cultured plants as described by Murashige and Skoog (1962). The $\mathrm{pH}$ of the MS medium was regulated at $5.7 \pm 0.1$ prior to add solidified agent then sterilized by autoclaving at $121^{\circ} \mathrm{C}$ for $20 \mathrm{~min}$. The medium was allocated into incubation jars where each jar contained $50 \mathrm{ml}$. Cultures were incubated at $25 \pm 2{ }^{\circ} \mathrm{C}$ and satisfactory fluorescent light of 3000 Lux for 16-hour 
photoperiod provided by cool, white, fluorescent lamps. Each treatment consisted of three replicates and each replicate was represented by 12 jars.

\section{2- Treatments:}

\section{A. Callus induction:}

For callus inducement, explants of both shoot tip and leaf explants were placed on MS basal medium $+1.0 \mathrm{mg} / \mathrm{l} \mathrm{BA}$ supplemented with different levels of 2,4-dichlorophenoxyacetic acid (2,4-D) at 0.0, 1.0, 2.0, 4.0 and $6.0 \mathrm{mg} / \mathrm{l}$. The percentage of callus formation (\%) and colour of callus were determined in order to find and the highest induction level of callus.

\section{B. Shoots induction:}

Resulted callus from shoots tip and leaf explants were used in the proliferation of shoots. Approximately $100 \pm 10 \mathrm{mg}$ fresh callus was placed in MS basal medium and supplemented with different concentrations of BA at $(0.0,1.0,2.0$ and $3.0 \mathrm{mg} / \mathrm{l})$ in combination with NAA at $(0.0$, 0.5 and $1.0 \mathrm{mg} / \mathrm{l}$ ) for inducing shoot formation. The Percentage of shoot formation (\%) and number of proliferated shoots were calculated.

\section{Root formation:}

Microshoots resulted from shoot induction scheme were moved into rooting medium. MS basal medium was supplemented with either IBA or IAA at $0.0,0.5,1.0$ and $2.0 \mathrm{mg} / \mathrm{l}$. Rooting percentage, average of root length and root number/plantlet were calculated after four weeks.

\section{Acclimatization:}

The complete plantlets were cleaned by current tap-water, and then sanitized by dipping roots in fungicide sol (Topspin, $1.0 \mathrm{~g} / \mathrm{L})$ and transferred to plastic pots $(7.5 \times 10.5 \mathrm{~cm})$ filled with a mixture medium of peat moss : vermiculite $(1: 1)$, vermiculite : sand $(1: 1)$ and peat moss + vermiculite + sand (1:1:1) by volume. Each treatment consisted of 20 pots. Each pot contained one plantlet. Pots were then transferred to the greenhouse and covered with polyethylene sheets to maintain high relative humidity around plants. In addition, spraying with water under the plastic sheets was carried out daily, while the irrigation took place 3 times a week. Survival percentage was recorded after 4 weeks from transplanting.

\section{Data elaboration process}

Experiments were designed in a completly randomized design. Each treatment was formed of 3 replicates of 4 jars each. Recorded results were assigned to proper statistical analysis of variance procedure. Means were separated by LSD test at 5\% error level of significance according to Snedecor and Cochran (1980). 


\section{RESULTS AND DISCUSSION}

\section{A. Callus induction:}

Data presented in Table (1) show that type of explants gave notable responses to different levels of 2,4-D. The MS medium devoid of 2,4-D did not demonstrate any callus initiation in both studied explants even when the culture period was prolonged. Callus initiation from leaf explants was conducted within 15 days of inoculation. Meanwhile, callus formation was observed in shoot tip explants within 21 days of inoculation. Data also indicated that leaf explant was more superior than shoot tip explant for callus production. This experiment showed that low level of 2,4-D application at 1.0 and $2.0 \mathrm{mg} / \mathrm{l}$ induced better calluses at the base of explants when compared to high concentrations (4.0 and $6.0 \mathrm{mg} / \mathrm{l}$ ). The maximum percentage of calluses formation was observed from both explants cultured on MS basal medium + BA supplemented with $2.0 \mathrm{mg} / \mathrm{l}$ 2,4-D. Both explants with the concentration of 2,4-D shared in the expression of various colour of callus. The colours of callus resulted from leaf explants were pale green, yellowish green, creamy and white globular and for shoot tip explant were creamy, whitish green, pale yellow and white at 1.0, 2.0, 4.0 and 6.0 mg/1 2,4-D.

The same result was obtained by Ojha et al., (2012), in which they reported that MS medium supplemented with 2,4-D and NAA was more efficient for encouraging callus of Stevia rebaudiana leaf explant than accompanied by other combinations of growth regulators. Jala (2014) mentioned that low concentration of 2,4-D was sufficient for callus induction from culturing stem node with axillary bud explants of miniature rose.

Table (1): Effect of different levels of 2,4-D for leaf and shoot tip explants of Jasminum polyanthum cultured for callus development after 2 months from cultured.

\begin{tabular}{|c|c|c|c|c|}
\hline \multirow[b]{2}{*}{$\begin{array}{l}2,4-D \\
(\mathrm{mg} / \mathrm{l})\end{array}$} & \multicolumn{2}{|c|}{$\begin{array}{l}\text { Percentage of callus } \\
\text { formation }(\%)\end{array}$} & \multicolumn{2}{|c|}{ Colour of callus } \\
\hline & $\begin{array}{c}\text { Leaf } \\
\text { explant }\end{array}$ & $\begin{array}{c}\text { Shoot tip } \\
\text { explant }\end{array}$ & $\begin{array}{c}\text { Leaf } \\
\text { explant }\end{array}$ & $\begin{array}{c}\text { Shoot tip } \\
\text { explant }\end{array}$ \\
\hline 0.0 & 0.0 & 0.0 & - & - \\
\hline 1.0 & 82 & 72.0 & pale green & creamy \\
\hline 2.0 & 91.3 & 89.3 & yellowish green & whitish green \\
\hline 4.0 & 74 & 63.0 & creamy & pale yellow \\
\hline 6.0 & 66 & 51.0 & white globular & white \\
\hline L.S.D at $5 \%$ & \multicolumn{2}{|c|}{2.11} & & \\
\hline
\end{tabular}

\section{B. Shoots induction:}

Data tabulated in Table (2) indicate that shoot induction (percentage and number) regenerated from callus culture in MS medium supplemented with different treatments were differed according to explants type and media composition as presented in Table (2). Leaf explant showed better shoot induction than shoot tip explant at both percentage of shoot formation and number of regenerated shoots. The highest percentages of shoot formation were 
obtained from the combination between BA $1.0 \mathrm{mg} / \mathrm{l}+$ NAA $0.5 \mathrm{mg} / \mathrm{l}$ from leaf explants $(91 \%)$ and shoot tip explant $(87.1 \%)$. The highest number of shoots per culture was found on MS+1.0 $\mathrm{mg} / \mathrm{l} \mathrm{BA}+0.5 \mathrm{mg} / \mathrm{l}$ NAA from leaf explant (8.4) and from shoot tip explant (7.3). Same results were obtained by Ojha, (2012) on Stevia rebaudiana and Biswal, (2014) on Jasminum sambac. BA has the potential to induce of regenerated shoot from callus. NAA had a mutual effect with BA in increasing proliferated shoots from induced callus of both explants. The shoot proliferation and multiplication were decreased when the concentration of NAA and BA is increased. The best results of new shoots regenerated from callus culture was attained at the application of $1.0 \mathrm{mg} / \mathrm{l} \mathrm{BA}+0.5 \mathrm{mg} / \mathrm{l} \mathrm{NAA}$ which encouraged both percentage and number of new regenerated shoot (Table 2 ).

Table (2): Influence of BA and NAA combinations on the induction of shoot after 2 months from cultured callus of leaf and shoot tip explants of Jasminum polyanthum.

\begin{tabular}{|c|c|c|c|c|}
\hline \multirow[t]{2}{*}{$\begin{array}{c}\mathbf{B A}+\mathbf{N A A} \\
(\mathrm{mg} / \mathrm{l})\end{array}$} & \multicolumn{2}{|c|}{$\begin{array}{c}\text { Shoot formation } \\
\text { percentage }(\%)\end{array}$} & \multicolumn{2}{|c|}{$\begin{array}{c}\text { Number of shoots per } \\
\text { culture }\end{array}$} \\
\hline & $\begin{array}{c}\text { Leaf } \\
\text { explant }\end{array}$ & $\begin{array}{c}\text { Shoot tip } \\
\text { explant }\end{array}$ & $\begin{array}{c}\text { Leaf } \\
\text { explant }\end{array}$ & $\begin{array}{c}\text { Shoot tip } \\
\text { explant }\end{array}$ \\
\hline BA 0.0 + 0.0 NAA & 0.0 & 0.0 & 0.0 & 0.0 \\
\hline BA $0.0+0.5$ NAA & 15.0 & 13.0 & 3.0 & 1.5 \\
\hline BA 0.0 + 1.0 NAA & 20.0 & 21.0 & 2.0 & 1.0 \\
\hline BA $1.0+0.0$ NAA & 70.0 & 69.0 & 6.3 & 4.5 \\
\hline BA 1.0 + 0.5 NAA & 91.0 & 87.1 & 8.4 & 7.3 \\
\hline BA 1.0 + 1.0 NAA & 60.0 & 55.3 & 4.5 & 3.3 \\
\hline BA $2.0+0.0$ NAA & 77.0 & 71.5 & 5.6 & 5.0 \\
\hline BA $2.0+0.5$ NAA & 75.1 & 72.3 & 6.7 & 5.7 \\
\hline BA 2.0 + 1.0 NAA & 57.3 & 48.1 & 4.0 & 3.7 \\
\hline BA $3.0+0.0$ NAA & 66.3 & 61.0 & 5.0 & 4.3 \\
\hline BA 3.0 + 0.5 NAA & 65.1 & 58.3 & 5.4 & 4.6 \\
\hline BA 3.0 + 1.0 NAA & 50.5 & 41.0 & 3.5 & 3.0 \\
\hline L.S.D at 5\% & \multicolumn{2}{|c|}{2.11} & \multicolumn{2}{|c|}{0.18} \\
\hline
\end{tabular}

\section{Rooting formation:}

Root formation on microshoots was influenced by the application of both auxins at different concentrations. Root formation percentage of Jasminum shoots culture was affected by both IBA and IAA at various levels that reached $100 \%$ for root formation. Whereas, free auxin medium showed absence of root formation. Increasing the levels of both auxins increase was positively correlated with the increase in root number and root length (Fig 1 and 2, respectively). IBA application showed better rooting formation and length when compared to IAA at each concentration. These result in agreement with Hartmann and Kester (1983) who noted that IBA is most often recommended as a rooting agent because it is less phytotoxic, over a broader range of concentrations and active in more species than IAA. IBA was significantly more stable 
than IAA to autoclaving, so the majority of IAA could be degraded under the same concentration. Similar results were obtained also by EL-Zeiny et al. (2013).

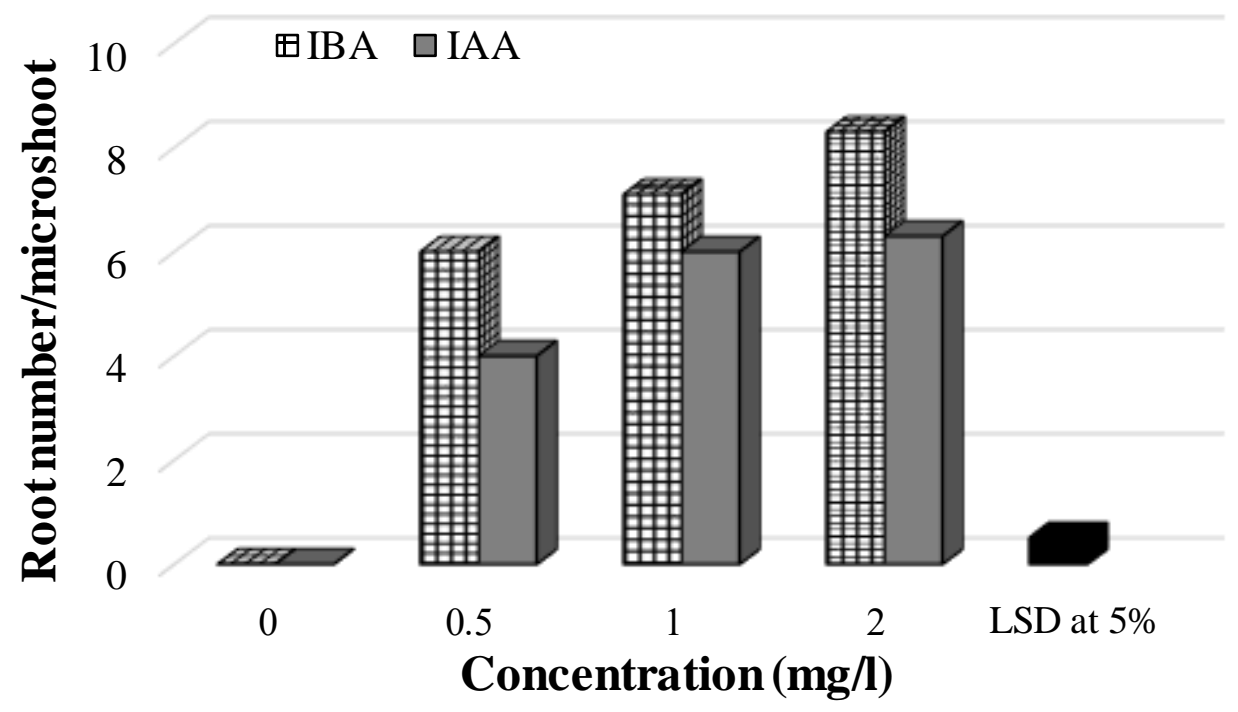

Fig (1): Effect of auxins on root number /microshoot production of Jasminum polyanthum developed from shoot tip culture.

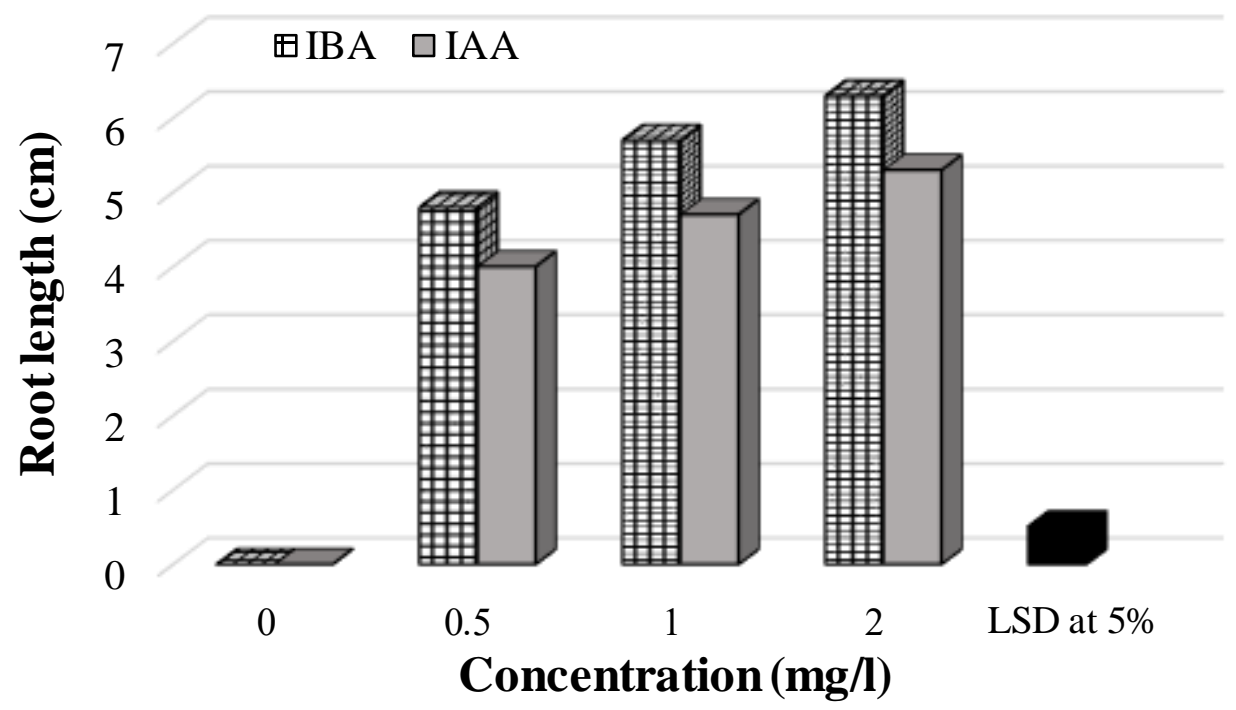

Fig (2): Effect of auxins on root length $(\mathrm{cm})$ per microshoot production of Jasminum polyanthum developed from shoot tip culture. 


\section{Acclimatization:}

Data presented in Fig (3) show that the potting medium containing peat moss + vermiculite gave the highest transplants survival percentage $91 \%$. Peat moss has highly valued physical growing media properties, viz. high porosity (about 74\%), small bulk density and high water holding capacity up to nine times its weight (Michel, 2010).

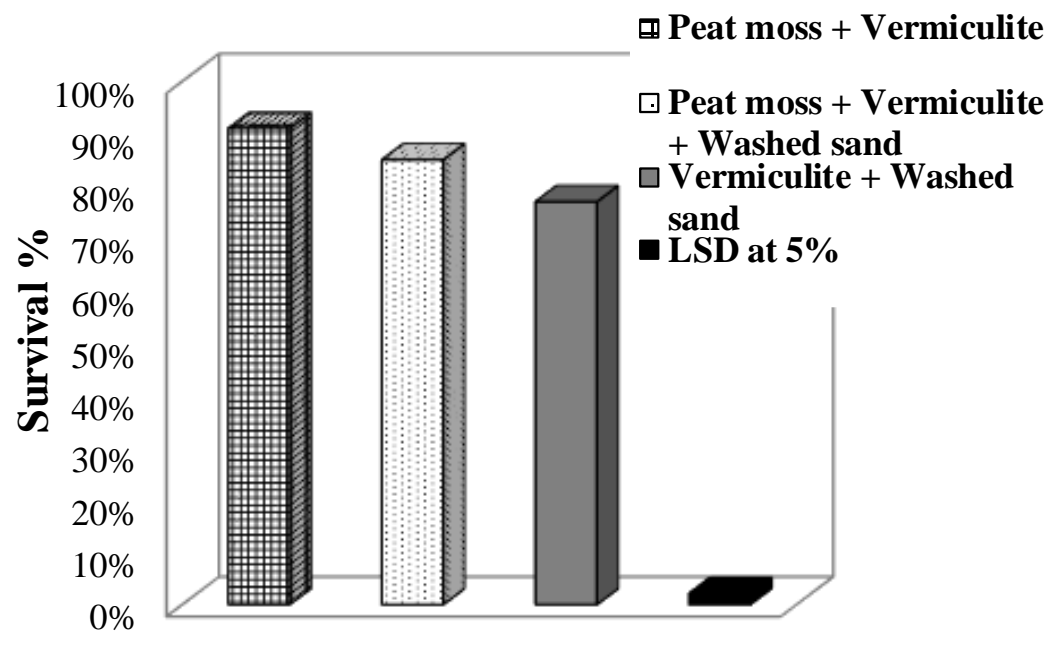

Fig (3): Effect of media substrate on survival percentage (\%) of Jasminum polyanthum plantlets.

\section{REFRENCES}

Bhattacharya, S., \& Bhattacharyya, S. (1997). Rapid multiplication of Jasminum officinale L. by in vitro culture of nodal explants. Plant cell, tissue and organ culture, 51(1), 57-60.

Bhattacharya, S., \& Bhattacharyya, S. (2010). In vitro propagation of Jasminum officinale L.: a woody ornamental vine yielding aromatic oil from flowers. In Protocols for In Vitro Propagation of Ornamental Plants (pp. 117-126). Humana Press.

Biswal, M. (2014). Studies on in-vitro propagation of jasmine (Jasminum sambac L. Aiton.) (MS.C. dissertation). Orissa University of Agriculture and Technology. BHUBANESWAR. India, (FLORICULTURE AND LANDSCAPING).

Dadlani, N.K. (1998). Cut flower production in India. In: Cut flower production in Asia. RAP Publ.

El-Zeiny, O.A.H; El-Behairy, U. A. A., Zocchi and M.M. Rashwan, (2013). Commercial production of globe artichoke (Cynara Scolymus L. in vitro. Egypt. J. Agric. Res., 91(3): 993-1006

Harrison, L. (2012). RHS Latin for Gardeners. United Kingdom: Mitchell Beazley. ISBN 184533731X. 224 pp. 
Hartmann, H.T. and Kester, D.E. (1983). Plant propagation, principles and practices. Section 16: ${ }^{\text {th }}$ Edition, Prentice-Hall. Inc., Englewood Cliffs, New Jersy.

Hassan, K.M., A.M. Hosni, M. Hewidy, A.B. AbdElrazik (2019). Micropropagation and evaluation of genetic stability of foxglove tree (Paulownia tomentosa). Arab Univ. J. Agric. Sci., Special Issue (2D): 2287- 2296.

Jain, A., Sharma, R., Kumar, A. and Sharma, S. (2011). Jasminum species: An overview, International Journal of Institutional Pharmacy and Life Sciences 1(1): pp. 251-259.

Jala, A. (2014). Role of 2,4-D on Callus Induction and Shoot Formation to Increase Number of Shoot in Miniature Rose In Vitro. American Transactions on Engineering \& Applied Sciences Volume 3 No.3 I. 207-213.

Jonard, R. (1989). Jasminum spp. (Jasmine): Micropropagation and the production of essential oils. In: Bajaj YPS (ed) Biotechnology in agriculture and forestry. medicinal and aromatic plants II, Vol. 7. Springer-Verlag, Berlin-Heidelberg, New York, pp 315-331

Michel, J.C. (2010). The physical properties of peat: a key factor for modern growing media. Mires and Peat, 6(2)1-6.

Murashige, T. and F. Skoog, (1962). A revised medium for rapid growth and bioassays with tobacco tissue culture. Physiol. plant, 15: 473-479.

Ojha, A., Kumar, S.; Singh, G.; and Tyagi. B.S. (2012). In vitro callus induction from leaf and stem explant of the natural sweetener plant, Stevia rebaudiana (Bertoni). African Journal of Biotechnology Vol. 11(34).

Papafotiou, M., Tsalouchos, N., Papagianni, A. and Bertsouklis, K.F. (2017). In vitro propagation of Lippia citriodora. Acta Hortic. 1155, 327-330.

Rahman, Md. S.; Mouri1, N. J.; Nandi1, N. C.; Akter, S and Khan, Md. S. (2018). In vitro micropropagation of Jasminum grandiflorum L. Bangladesh J. Sci. Ind. Res. 53(4), 277282.

Snedecor, G.W and Cochran W.G. (1980). Statistical Methods. Sixth. Edition, Iowa State Univ. Press, Amer., Iowa. USA Swartz. 593 pp. 